\title{
Editorial
}

\section{A importância da parceria para a divulgação da produção científica em Psicologia}

Temos enormes carências de produção em todas as áreas do conhecimento quando nos comparamos a países chamados de primeiro mundo... No VIII Encontro de Editores Científicos, promovido pela Associação Brasileira de Editores Científicos (ABEC) em Atibaia-SP, foram apresentados dados referentes à produção científica nacional e estrangeira, o que tornou bastante visível as diferenças entre nós e os 'outros'. Tendo sido criada em 1985, esta associação tem contribuído, especialmente, para aprimorar o padrão da forma e conteúdo das publicações técnico-científicas no país e favorecer a capacitação das pessoas responsáveis por elas.

Mesmo tendo muito a caminhar, alguns avanços importantes, recentemente ocorridos, são muito significativos e apontam para possibilidades inimagináveis há poucos anos. O programa SciELO Scientific Electronic Library Online, da BIREME, é um exemplo de ações concretas que são bastante animadoras. Com a colaboração da FAPESP, este programa conseguiu incluir mais de 40 periódicos brasileiros de diversas áreas e tem como meta selecionar um total de 100 revistas. Há exigências rigorosas que devem ser seguidas para que uma revista científica possa ser incluída nesta base de dados, o que sem dúvida contribuirá para que as publicações brasileiras melhorem acentuadamente, procurando alcançar os padrões estabelecidos para poderem ganhar a visibilidade que a inclusão no SciELO possibilita.

Durante o Encontro de Editores Científicos ficou claro que a busca de parceria, bem como a troca de experiências, é extremamente rica e favorecedora de condições que propiciam a melhoria na qualidade das publicações nacionais. As reuniões realizadas por área possibilitaram a partilha entre quem já caminhou muito com quem está apenas começando. Assim, tivemos a presença de editores de revistas, das mais tradicionais às mais recentes, até os de algumas que ainda não foram lançadas. Com referência específica à área de Psicologia, houve ganhos bastante expressivos. Algumas idéias já se transformaram em iniciativas concretas, tal como a Lista de Discussão dos Editores da Área, que já está em funcionamento, consistindo num canal importante de comunicação. Além disso, discutiu-se o encaminhamento de uma proposta de atividades variadas (workshops; mini-cursos e painéis permanentes das revistas) a serem inseridas no programa do I Congresso de Psicologia: Ciência e Profissão. É importante usufruirmos plenamente da oportunidade de aprofundar o diálogo iniciado entre as muitas publicações existentes na área, pois com isso nos tornamos mais visíveis aos profissionais e aos estudantes, que são os pesquisadores e profissionais do futuro, consumidores e produtores da ciência. 
A ABRAPEE, como sociedade científica e profissional, está a cada dia mais consciente de sua responsabilidade no que se refere à divulgação do conhecimento científico. Para tanto, vale enfatizar os critérios rigorosos pelos quais procura pautar a sua principal publicação - a Psicologia Escolar e Educacional, que tem como objetivo ser uma revista acessível e dar visibilidade aos resultados de pesquisas produzidas na área. Com o esforço conjunto e a colaboração de pesquisadores de excelência na área, associado à utilização do sistema de avaliação (às cegas) conseguiremos nossa indexação em novos Bancos de Dados nacionais e internacionais e garantiremos que os objetivos pretendidos sejam alcançados.

Acácia Aparecida Angeli dos Santos

Presidente atual 